\title{
A VITAMIN A-FREE DIET RESULTS IN IMPAIRMENT OF THE RAT HIPPOCAMPAL SOMATOSTATINERGIC SYSTEM
}

\section{A. M. HERNÁNDEZ-PINTO, L. PUEBLA-JIMÉNEZ AND E. ARILLA-FERREIRO*}

Grupo de Neurobioquímica, Departamento de Bioquímica y Biología Molecular, Facultad de Medicina, Crta. Madrid-Barcelona Km. 33,6, Universidad de Alcalá de Henares, E-28871 Alcalá de Henares, Madrid, Spain

\begin{abstract}
Previous studies have revealed the presence of retinoid specific receptors in the hippocampus and have demonstrated that vitamin A deficiency produces a severe deficit in spatial learning and memory which are linked to a proper hippocampal functioning. It is also well known that the tetradecapeptide somatostatin binds to specific receptors in the hippocampus and, when injected into this brain area, facilitates the acquisition of spatial tasks. In addition, depletion of somatostatin by cysteamine impairs acquisition of these tasks. Taken together, these studies support the idea that the hippocampal somatostatinergic system might be regulated by vitamin A. Hence, we evaluated the effects of vitamin A deprivation and subsequent administration of vitamin A on the rat hippocampal somatostatinergic system. Rats fed a vitamin A-free diet exhibited a significant reduction of somatostatin-like immunoreactivity content in the hippocampus whereas the somatostatin mRNA levels were unaltered. Vitamin A deficiency increased the somatostatin receptor density and its dissociation constant. Functional Gi activity as well as the capacity of somatostatin to inhibit basal and forskolin-stimulated adenylyl cyclase activity was decreased in vitamin A deficiency rats as compared with the control animals. All these parameters were fully restored when vitamin A was replaced in the diet. Furthermore, we found that the $\mathrm{Gi} \alpha_{1}, \mathbf{G i} \alpha_{2}$ and $\mathrm{Gi} \alpha_{3}$ protein levels were unaltered in hippocampal membranes from rats fed a vitamin A-free diet whereas subsequent vitamin $\mathrm{A}$ administration to these rats caused a significant increase in the levels of $\mathrm{Gi} \alpha 1$ and $\mathrm{Gi} \alpha 2$. Altogether, the present findings suggest that dietary vitamin A levels modulate the somatostatinergic system in the rat hippocampus. () 2006 IBRO. Published by Elsevier Ltd. All rights reserved.
\end{abstract}

${ }^{*}$ Corresponding author. Tel: +34-91-885-45-09; fax: +34-91-885-45-85. E-mail address: lilian.puebla@uah.es (E. A. Ferreiro).

Abbreviations: AC, adenylyl cyclase; BSA, bovine serum albumin; cAMP, cyclic AMP; CREB, cyclic AMP response element-binding; EDTA, ethylenediaminetetraacetic acid; FK, forskolin; Gpp(NH)p, 5'-guanylylimidodiphosphate; GR, glucocorticoid receptor; GTP, guanosine triphosphate; HPLC, high performance liquid chromatography; IBMX, 3-isobutyl-1-methylxantine; LTD, long-term depression; LTP, long-term potentiation; MMLV-RT, Moloney murine leukemia virus reverse transcriptase; $\mathrm{PC} 2$, proprotein convertase 2; PCR, polymerase chain reaction; PMSF, phenylmethylsulfonyl fluoride; proSS, prosomatostatin; RA, retinoic acid; RAR, retinoic acid receptor; $R T$, reverse transcription; RXR, retinoid "X" receptor; SDS, sodium dodecylsulfate; SDS-PAGE, polyacrylamide gel electrophoresis in the presence of SDS; SS, somatostatin; SS-LI, SS-like immunoreactivity; sst, somatostatin receptor; SS-14, somatostatin-14; VA, vitamin A; VAD, vitamin A deficiency.
Key words: retinoic acid, retinoids, somatostatin, hippocampus.

Retinoids (vitamin A (VA) derivatives) play an important role during embryogenesis in the development of several tissues and thereafter in the maintenance of functions such as vision, growth, immune response and reproduction (Dowling and Wald, 1960; Thompson et al., 1964; Maden et al., 1998). The biological effects of the retinoids are mediated by retinoid receptors, a subgroup of the nuclear receptor superfamily. The retinoid receptor family includes the retinoic acid receptor (RAR) $\alpha, \beta$ and $\gamma$, which are able to bind all-trans and 9-cis stereoisomers of retinoic acid (RA) and the retinoid $\mathrm{X}$ receptors (RXR) $\alpha, \beta$ and $\gamma$, which specifically bind 9-cis RA (Mangelsdorf et al., 1995; Chambon, 1996). These receptors belong to the steroid/thyroid hormone nuclear receptor superfamily and function as transcription factors by binding to retinoid response elements in the promoter of target genes, predominantly in the form of RAR/RXR heteroisomers (Mangelsdorf and Evans, 1995; Kastner et al., 1997). Retinoid receptors have been identified in numerous tissues, including liver, kidney, spleen, testis, lung, spinal cord and brain (Zhuang et al., 1995). A role for all-trans-retinoic-acid (ATRA) in the physiological function of the hippocampus is suggested by the presence of components of retinoid signaling pathways (Lane and Bailey, 2005). Retinal dehydrogenase 2 protein, one of the enzymes that synthesizes RA, is restricted to the meninges surrounding the hippocampus in the adult mouse brain (Wagner et al., 2002). Immunoreactivity for the cellular retinol binding protein I (CRBP-I) and cellular retinoic acid-binding protein I (CRABP-I) has been demonstrated in the dendritic layers of the hippocampal formation and the dentate gyrus (Zetterström et al., 1994). In addition, $\operatorname{RAR} \alpha$ and $\operatorname{RXR} \alpha, \beta, \gamma$ mRNA transcripts have been detected in the hippocampus (Zetterström et al., 1999).

It has recently been found that transgenic mice lacking RAR (RAR $\beta / R X R \gamma$ ) have impaired hippocampal longterm potentiation (LTP) and long-term depression (LTD) (Chiang et al., 1998), which are generally believed to constitute a physiological mechanism for learning and memory (Bliss and Collingridge, 1993). Mice deprived postnatally of vitamin $A(V A)$, at the age of 12 weeks, showed a reduction of hippocampal CA1 LTP and LTD (Misner et al., 2001). In these VA-deprived mice, the synaptic LTP and LTD activity was restored when animals were returned to a diet containing VA. More recently, it has been found that VA deficiency produces spatial learning and memory impairment in rats (Cocco et al., 2002) and mice (Etchamendy et al., 
2003). Recent evidence also indicates that various neuropeptides located in cortical and subcortical brain regions have a role in cognitive behavior (Bennett et al., 1997).

The tetradecapeptide somatostatin-14 (SS-14) has been demonstrated to be involved in cognitive functions (Schettini, 1991; Bissette and Myers, 1992). This neuropeptide enhances the LTP phenomenon in the mossy fiber-CA3 pathway of the hippocampus in vitro (Matsuoka et al., 1991). More precisely, it has been suggested that somatostatinergic neurons intrinsic to the hippocampal formation are a critical component of a neuronal mechanism controlling the information processing function of the hippocampus (Guillou et al., 1998). Previous experiments have provided evidence for a facilitatory effect of brain SS-14 on spatial learning. In particular, intrahippocampal injections of SS-14 have been shown to enhance the rate of acquisition of a spatial discrimination task in the eightarm radial maze (Guillou et al., 1998). In contrast, both intrahippocampal and systemic injections of cysteamine, a depleter of SS-14 stores, was found to slow down the rate of acquisition in the radial-arm maze (Sessions et al., 1989; Guillou et al., 1998) and water maze (Fitzgerald and Dokla, 1989; Matsuoka et al., 1995) spatial tasks.

Somatostatin (SS) is a potent neuropeptide which exists in two biologically active forms, SS-14 and its amino terminally extended form, SS-28. Mammalian SS biosynthesis involves the proteolytic processing of a single precursor molecule, prosomatostatin (proSS). This molecule is a physiological substrate of prohormone or proprotein convertase 2 (PC2) in vivo, which leads to the generation of brain SS-14 (Winsky-Sommerer et al., 2003, 2000).

SS has a widespread distribution throughout the CNS and peripheral nervous system. In the hippocampus, it is expressed mainly in dendritic inhibitory cells. The dendritic inhibitory cells correspond with previously reported oriens/ alvens interneurons with lacunosum-moleculare axon arborization (O-LM; Sik et al., 1995) and hilar perforant pathassociated neurons (HIPP cells; Han et al., 1993). The dendritic inhibitory neurons exhibit a dense terminal plexus in the stratum lacunosum-moleculare of the Ammon's horn and in the molecular layer of the dentate gyrus (Freund and Buzsaki, 1996). A subset of SS-like immunoreactivity (SS-LI) neurons in the hippocampus project to the medial septum (Zappone and Sloviter, 2001).

Five distinct somatostatin receptor subtypes (sst 1-5) have been characterized and shown to be members of the seven transmembrane-spanning, G-protein-coupled superfamily of receptors (Csaba and Dournaud, 2001). These receptors regulate diverse signal transduction pathways such as adenylyl cyclase (AC) and guanylyl cyclase inhibition, phospholipase $C$ and phospholipase $A_{2}$ stimulation, tyrosine phosphatase activation or modulation of ionic conductance channels (Meyerhof, 1998).

SS binds to specific receptors in the hippocampus and when injected into this brain area, facilitates, the acquisition of spatial tasks. In addition, depletion of SS by cysteamine, impairs acquisition of these tasks. On the other hand, vitamin A deficiency (VAD) has been shown to produce a severe deficit in spatial learning and memory which are linked to a proper hippocampal functioning. Taken together, these studies support the idea that the somatostatinergic system in the hippocampus might be regulated by VA. Thus, we analyzed the effect of a VA-free diet and subsequent administration of VA on the SS-LI levels, SS mRNA levels, binding of ${ }^{125} \mathrm{I}$-Tyr ${ }^{11}$-SS to specific Sst, the protein levels of the Sst subtypes sst1-4, the functionality of $\mathrm{Gi}$ proteins, $\mathrm{Gi}(\mathrm{Gi} \alpha 1, \mathrm{Gi} \alpha 2$ and $\mathrm{Gi} \alpha 3$ ) protein levels as well as basal and forskolin (FK)-stimulated AC activity in the rat hippocampus.

\section{EXPERIMENTAL PROCEDURES}

\section{Materials}

Synthetic Tyr ${ }^{11}$-SS and SS tetradecapeptide were purchased from Universal Biological Ltd. (Cambridge, UK); carrier-free ${ }^{125} \mathrm{Nal}$ (IMS $100 \mathrm{mCi} / \mathrm{ml}$ ) was purchased from the Radiochemical Center (Perkin Elmer, Boston, MA, USA); bacitracin, bovine serum albumin (BSA), butylated hydroxytoluene, EDTA, FK, hexane, phenylmethylsulfonyl fluoride (PMSF), guanosine triphosphate (GTP), ATP, 5'-guanylylimidodiphosphate $(\mathrm{Gpp}(\mathrm{NH}) \mathrm{p}), \quad$ 3-isobutyl-1methylxantine (IBMX) and other reagents for sodium dodecylsulfate-polyacrylamide gel electrophoresis (SDS-PAGE) and for high-performance liquid chromatography (HPLC) were from Sigma (Madrid, Spain). Specific antiserum against the $\alpha \mathrm{i} 1$ (MAB 3075 ) or $\alpha \mathrm{i} 2$ (MAB 3077) G proteins subunits were obtained from Chemicon International (Temecula, CA, USA). Specific antisera against the $\alpha \mathrm{i} 3 \mathrm{G}$ protein subunit (sc-262) or against the Sst subtypes 1-4 (sc-11604, sc-11606, sc-11614, sc-11619) were obtained from Santa Cruz Biotechnology Inc. (Santa Cruz, CA, USA). Specific antiserum against beta tubulin ( $\beta$-tub) (T-4026) was purchased from Sigma. Nitrocellulose and nylon membranes as well as the chemiluminescence Western blotting detection system, $\left({ }^{32} \mathrm{P}\right)$ deoxyadenosine 5 'triphosphate and the radiolabeling system used to label the DNA probe, were purchased from Amersham (Buckinghamshire, UK). TriReagent for RNA isolation was from Molecular Research Center (Cincinnati, OH, USA). DNase I Rnase-free was purchased from Roche Applied Science (Indianapolis, IN, USA). Moloney murine leukemia virus reverse transcriptase (MMLV-RT) and other reagents for the reverse transcription reaction (RT) were obtained from Invitrogen Ltd. (BarceIona, Spain). Dextran T-70 and charcoal Norit A were obtained from Serva Feinbiochemica (Heidelberg. Germany). The rabbit antibody used in the radioimmunoassay technique was purchased from the Radiochemical Centre (Amersham). This antiserum was raised in rabbits against SS-14 conjugated to BSA and is specific for SS but, since SS-14 constitutes the C-terminal portions of both SS-25 and SS-28, the antiserum does not distinguish between these three forms.

\section{Experimental animals}

The animal experiments performed in the present study conform to the guidelines of the Animal Care Committee of Alcalá University, and all the experimental protocols have been approved. Great care was taken to avoid or minimize discomfort to the animals. Male Sprague-Dawley rats (20 days of age) (Harlan, Barcelona, Spain) weighing 70-90 g were used in this study. Animals were maintained on a 12-h light/dark cycle (07:00-19:00 h) and allowed free access to food and water. The number of animals used (20) was the minimum strictly necessary.

The experimental design of VAD was the same as that described by Cocco et al. (2002). Briefly, one group of five rats received the diet lacking vitamin $A$ (VAD), whereas a second group (five rats) was fed with standard laboratory chow (controls). The VA-free diet (Laboratory, Piccioni, Segrate, Italy), for $100 \mathrm{~g}$ of 
food, dry weight, was composed of: vitamin-free casein, $18 \%$; sucrose plus maize starch, $68.4 \% ; 2 \%$ cellulose; hydrogenated coconut oil, $4.6 \%$; Hegsted salt, $4.8 \%$; yeast, $2 \%$ plus a vitamin integration lacking VA, $0.2 \%$. The animal weight was monitored daily during the experimental period. Following 12 weeks of the VA-free diet, on appearance of the first symptoms of VAD, five rats were fed using the diet reported above with an additional supplement of VA (15,000 U.I./kg diet). Another group of five rats was fed using the same VA-supplemented chow following 12 weeks of a standard laboratory chow.

In all experimental groups, the brains were rapidly removed and the hippocampus was dissected on ice according to the method of Glowinski and Iversen (1996).

\section{Determination of plasma total retinol concentration}

Analysis of plasma retinol levels was performed by reverse phase HPLC according to the method of Bieri et al. (1979). Briefly, blood samples were collected in EDTA-coated tubes and frozen in dark at $-70^{\circ} \mathrm{C}$ until determination of retinol concentrations (Oliveros et al., 2000). Retinoids were extracted from plasma (100 $\mu \mathrm{l})$ into hexane containing $5 \mu \mathrm{g}$ of butylated hydroxitoluene $/ \mathrm{ml}$ as antioxidant for analysis. Retinol and internal standard (retinyl acetate) were extracted into hexane for HPLC. Chromatography was performed on a C-18 HPLC column with $100 \%$ methanol as the mobile phase. Retinol was detected by UV absorbance at $325 \mathrm{~nm}$ (Hewlett Packard HPLC 1050 System).

\section{Tissue extraction and SS radioimmunoassay}

For SS-LI measurements, the hippocampus was rapidly homogenized in $1 \mathrm{ml}$ of $2 \mathrm{M}$ acetic acid using a Brinkman polytron (setting $5,30 \mathrm{~s}$ ). The extracts were boiled for $5 \mathrm{~min}$ in a waterbath, chilled in ice, and aliquots $(100 \mu \mathrm{l})$ were removed for protein determination (Lowry et al., 1951). The homogenates were subsequently centrifuged at $15,000 \times g$ for $15 \mathrm{~min}$ at $4{ }^{\circ} \mathrm{C}$ and the supernatant was neutralized with $2 \mathrm{M} \mathrm{NaOH}$. The extracts were then stored at $-70{ }^{\circ} \mathrm{C}$ until assay. The tissue concentration of SS-LI was analyzed in the extracts by a competitive radioimmunoassay, as previously reported (Patel and Reichlin, 1978), with a sensibility limit of $10 \mathrm{pg} / \mathrm{ml}$. All samples from a given brain region were assayed on the same RIA run. Incubation tubes prepared in duplicate contained $100 \mu \mathrm{l}$ samples of unknown or standard solutions of $0-500 \mathrm{pg}$ cyclic SS tetradecapeptide diluted in phosphate buffer $(0.1 \mathrm{M}, \mathrm{pH} 7.5$ containing $0.2 \%$ BSA, $0.1 \%$ sodium azide), $200 \mu \mathrm{l}$ of appropriately diluted anti-SRIF serum, $100 \mu \mathrm{l}$ of

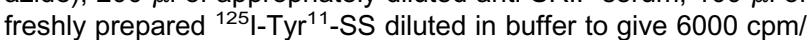
assay tube (equivalent to $5-10 \mathrm{pg}$ ), and enough buffer to give a final volume of $0.8 \mathrm{ml}$. All reagents, as well as the assay tubes, were kept chilled in ice before their incubation for $24 \mathrm{~h}$ at $4{ }^{\circ} \mathrm{C}$. Separation of bound and free hormone was accomplished by the addition of $1 \mathrm{ml}$ of dextran-coated charcoal (dextran: $0.2 \% \mathrm{w} / \mathrm{v}$ charcoal: $2 \% \mathrm{w} / \mathrm{v}$ ). Serial dilution curves for the samples were parallel to the standard curve.

\section{Membrane preparations}

The hippocampus was homogenized in $10 \mathrm{mM}$ HEPES-KOH buffer, $\mathrm{pH} 7.6(10 \% \mathrm{wt} / \mathrm{vol})$, with a Brinkmann polytron homogenizer (setting $5,15 \mathrm{~s}$ ). The homogenate was spun at $600 \times \mathrm{g}$ for 5 $\min$ at $4{ }^{\circ} \mathrm{C}$, and the supernatant was centrifuged at $48,000 \times g$ for $30 \mathrm{~min}$ at $4{ }^{\circ} \mathrm{C}$. The resulting pellet was suspended in $10 \mathrm{mM}$ HEPES- $\mathrm{KOH}, \mathrm{pH} 7.6(10 \% \mathrm{w} / \mathrm{v})$ and then centrifuged as before. The resultant pellet was resuspended in $50 \mathrm{mM}$ Tris- $\mathrm{HCl}$ buffer (pH 7.5). Samples were stored at $-70{ }^{\circ} \mathrm{C}$ until the day of assay.

\section{Binding assay}

$\mathrm{Tyr}^{11}$-SS was radioiodinated by chloramine-T iodination according to the method of Greenwood et al. (1963). The tracer was purified in a Sephadex G-25 fine column $(1 \times 100 \mathrm{~cm})$ equilibrated with $0.1 \mathrm{M}$ acetic acid containing $0.1 \% \mathrm{BSA}(\mathrm{w} / \mathrm{v})$. The specific activity of the purified labeled peptide was about $600 \mathrm{Ci} / \mathrm{g}$.

Hippocampal membranes were prepared as previously described by Reubi et al. (1981). Protein concentration was assayed by the method of Lowry et al. (1951), with BSA as a standard. Specific SS binding was measured according to the modified method of Czernik and Petrack (1983). Briefly, the membranes $(0.15 \mathrm{mg}$ protein $/ \mathrm{ml})$ were incubated in $250 \mu \mathrm{l}$ of a medium containing $50 \mathrm{mM}$ Tris- $\mathrm{HCl}$ buffer ( $\mathrm{pH} 7.5), 5 \mathrm{mM} \mathrm{MgCl}_{2}, 0.2 \mathrm{mg} / \mathrm{ml}$ bacitracin with $250 \mathrm{pM}^{125} \mathrm{I}-\mathrm{Tyr}^{11}$-SS either in the absence or presence of $0.01-10 \mathrm{nM}$ unlabeled SS. After a 60 min incubation at $30{ }^{\circ} \mathrm{C}$, bound and free ligand were separated by centrifugation at $11,000 \times g$ for $2 \mathrm{~min}$. The supernatant was discarded and the pellet was washed with Tris $(50 \mathrm{mM})-$ sucrose $(0.9 \%)$ buffer $(\mathrm{pH}$ 7.4). The radioactivity in the pellet was measured with a gamma counter. Nonspecific binding was obtained from the amount of radioactivity bound in the presence of $10^{-7} \mathrm{M} \mathrm{SS}$ and represented about $20 \%$ of the binding observed in the absence of unlabeled peptide. This non-specific component was subtracted from the total bound radioactivity in order to obtain the corresponding specific binding.

\section{Evaluation of radiolabeled peptide degradation}

To determine the extent of tracer degradation during incubation, we measured the ability of pre-incubated peptide to bind to fresh membranes as previously described (Aguilera et al., 1982). Briefly, ${ }^{125} \mathrm{I}-\mathrm{Tyr}^{11}$-SS (250 pM) was incubated with membranes from the rat hippocampus $(0.15 \mathrm{mg}$ protein $/ \mathrm{ml})$ for $60 \mathrm{~min}$ at $30^{\circ} \mathrm{C}$. After this pre-incubation, aliquots of the medium were added to fresh membranes and incubated for an additional $60 \mathrm{~min}$ at $30^{\circ} \mathrm{C}$. The fraction of the added radiolabeled peptide which was specifically bound during the second incubation was measured and expressed as a percentage of the binding that had been obtained in control experiments performed in the absence of membranes during the pre-incubation period.

\section{AC assay}

AC activity was measured as previously reported (Houslay et al., 1976), with minor modifications. Briefly, hippocampal membranes $(0.06 \mathrm{mg} / \mathrm{ml})$ were incubated with $1.5 \mathrm{mM} \mathrm{ATP}, 5 \mathrm{mM}$ $\mathrm{MgSO}_{4}, 10 \mu \mathrm{M}$ GTP, an ATP-regenerating system $(7.5 \mathrm{mg} / \mathrm{ml}$

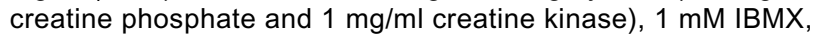
$0.1 \mathrm{mM}$ PMSF, $1 \mathrm{mg} / \mathrm{ml}$ bacitracin, $1 \mathrm{mM}$ EDTA, and test substances $\left(10^{-4} \mathrm{M}\right.$ SS or $\left.10^{-5} \mathrm{M} \mathrm{FK}\right)$ in $0.1 \mathrm{ml}$ of $0.025 \mathrm{M}$ triethanolamine/ $\mathrm{HCl}$ buffer $(\mathrm{pH} 7.4)$. After a 15 min incubation at $30^{\circ} \mathrm{C}$, the reaction was stopped by heating the mixture for 3 min at $100{ }^{\circ} \mathrm{C}$. After cooling, $0.2 \mathrm{ml}$ of an alumina slurry $(0.75 \mathrm{~g} / \mathrm{ml}$ in triethanolamine $/ \mathrm{HCl}$ buffer, $\mathrm{pH}$ 7.4) was added and the suspension was centrifuged. The supernatant was taken for assay of cyclic AMP (cAMP) by the method of Gilman (1970). The SS concentration used was that necessary to achieve inhibition of rat brain AC activity (Schettini et al., 1989). FK was used at a concentration that could effectively stimulate the catalytic subunit of rat AC (Schettini et al., 1989).

\section{$\mathrm{RT}$, polymerase chain reaction (PCR) and Southern blotting}

Total RNA was isolated from the hippocampus in guanidinium isothiocyanate, using a commercial kit (Tri Reagent). The total RNA samples were digested with DNase I, purified with phenolchloroform-isoamyl alcohol $(1: 1: 0.02)$ and stored at $-70^{\circ} \mathrm{C}$ until analysis. The RNA concentration and purity in the final preparation were spectrophotometrically quantified by measuring the absorbance at 260 and $280 \mathrm{~nm}$ (Ultrospec Plus UV/Vis Spectrophotom- 
Table 1. Nucleotide sequence of the PCR primers used and the size of the amplified products

\begin{tabular}{lll}
\hline Gene & Sequence & Size (bp) \\
\hline SS & & \\
Sense & 5'-GATGCTGTCCTGCCGCCTCCAG-3' & \multirow{2}{*}{356} \\
Antisense & 5'-ACAGGATGTGAAAGTCTTCCA-3' & \\
$\beta$-act & & \\
$\quad$ Sense & 5'-TGACCCAGATCATGTTTGAGA-3' $^{4} 484$ \\
Antisense & 5'-ACTCCATGCCCAGGAAGGA-3' & \\
\hline
\end{tabular}

eter, Pharmacia Biotech, Sweden). The RNA integrity was checked on a denaturing $1.5 \%$ agarose gel stained with ethidium bromide.

Total RNA $(1 \mu \mathrm{g})$ was primed with Oligo(dT) ${ }_{12-18}$ and incubated with MMLV-RT to synthesize cDNA. The following negative control for RT-PCR was performed: RT reaction in absence of MMLV-RT as a control of genomic DNA contamination.

For amplification by PCR, the SS primers and conditions used were those previously described (Schwartz and Vallejo, 1998). $\beta$-actin ( $\beta$-act) primers were added as an internal standard (Karbownik et al., 2005) (Table 1).

Following PCR, the samples were run on an agarose gel (with a density gradient of $2 \%-1.5 \%-1 \%$ ) and the bands were visualized after staining with ethidium bromide.

Southern blotting was performed according to a previously described method (Sambrook et al., 1989). The blot was probed with a ${ }^{32} \mathrm{P}$-labeled internal primer that anneals to the $5^{\prime}$-region of exon 2 of the SS gene (Schwartz and Vallejo, 1998) (5'-TTCGACTTGGCAGACCTCTGCAGCTCCAGCCT-3') and autoradiographed at $-70{ }^{\circ} \mathrm{C}$.

\section{Immunodetection of Sst subtypes and $\alpha \mathrm{i}$ subunits of $\mathbf{G}$ proteins}

Membranes $(100 \mu \mathrm{g})$ were solubilized in sodium dodecyl sulfate (SDS)-sample buffer and the proteins were then run on a $12 \%$ SDS-polyacrylamide gel. The transfer of proteins to nitrocellulose membranes and the immunodetection of the Sst subtypes 1-4 (sst1-4) or the $\alpha \mathrm{i}_{1-3} \mathrm{G}$ protein subunits using specific antibodies, were carried out as described elsewhere (Mumby et al., 1986). Briefly, after protein transfer, the nitrocellulose membranes were pre-incubated with blotting buffer [50 mM Tris- $\mathrm{HCl}, \mathrm{pH} 7.5$; $150 \mathrm{mM} \mathrm{NaCl} ; 0.05 \%(\mathrm{v} / \mathrm{v})$ Tween-20, and $5 \%(\mathrm{w} / \mathrm{v})$ non-fat dry milk]. Antisera were diluted in the same buffer without non-fat dry milk (dilution 1/1000) and were then added to the nitrocellulose membranes. Incubation was carried out overnight at $4{ }^{\circ} \mathrm{C}$. Subsequently, excess antibody was removed and three 15-min washes with blotting buffer were performed. After washing, the bound immunoreactive proteins were incubated with horseradish peroxidase-conjugated antibodies to IgG (dilution 1/2000) for 60 min at $4{ }^{\circ} \mathrm{C}$ for the immunodetection of the sst1-4 or $\alpha \mathrm{i}_{1-3} \mathrm{G}$ protein subunits. After eliminating unbound antibody, three 5-min washes with HEPES $20 \mathrm{mM} \mathrm{pH} 7.5$ were carried out and the proteins were detected by chemiluminescence using an ECL Western blotting detection kit according to the manufacturer's instructions. X-ray films (Hyperfilm ECL) were exposed for $30 \mathrm{~s}$ to 1 min. Quantification of the bands was carried out by densitometric analysis using the Scion Image computer program (Scion Inc., Frederick, MD, USA).

\section{Data analysis}

The computer program LIGAND (Munson and Rodbard, 1980) was used to analyze the binding data. The use of this program enables models of receptors that best fit the given sets of data to be selected. The same program was also used to present the data in the form of Scatchard plots (Scatchard, 1949) and to compute values for receptor affinity $\left(K_{\mathrm{d}}\right)$ and density $\left(B_{\max }\right)$ that best fit the sets of binding data for each rat. Statistical comparisons of all the data were carried out with one way analysis of variance and the Student-Newman-Keuls test. Means among groups were considered significantly different when the $P$ value was less than 0.05. Each individual experiment was performed in duplicate.

\section{RESULTS}

Rats fed a VA-free diet showed a significant reduction in body weight gain as compared with control rats. The average difference between body weight after 12 weeks was $40.3 \pm 7.1 \mathrm{~g}$ (Fig. 1). The plasma retinol concentration in rats fed the VA-deficient diet was significantly lower $(P<0.01)$ than that of the control group $(0.73 \pm 0.12 \mu \mathrm{mol} / \mathrm{l}$ vs. $2.10 \pm 0.4$ $\mu \mathrm{mol} / \mathrm{l}$, respectively). Values are the means \pm S.E.M. of five rats per dietary group.

As shown in Fig. 2, a VA-free diet during 12 weeks decreased SS-LI levels $(85.25 \%$ decrease, $P<0.001)$ in the rat hippocampus in comparison with the control animals but did not affect the SS mRNA levels (Figs. 3 and 4). VA administration during one week to the rats fed the VA-free diet reversed the reduction of SS-LI levels in the hippocampus to control values.

A VA-free diet during 12 weeks produced a significant increase in ${ }^{125} \mathrm{I}-\mathrm{Tyr}^{11}$-SS binding to rat hippocampal membranes as compared with control animals. This increase was due to a rise in the maximal number of Sst, as revealed by Scatchard plots of the binding data (Fig. 5). In addition, a significant decrease in the receptor affinity was observed (Table 2). VA administration to these rats fed a VA-free diet reversed the binding parameters to control values.

To test if the VA-free diet had an effect on a specific Sst subtype, Western blot analyses of sst1-4 were performed in the rat hippocampal membranes. A significant increase in the protein levels of sst1-sst4 was observed (Table 3). Subsequent VA administration to these rats fed a VA-free diet normalized the sst1, sst3 and sst4 protein levels, whereas the sst2 levels remained elevated.

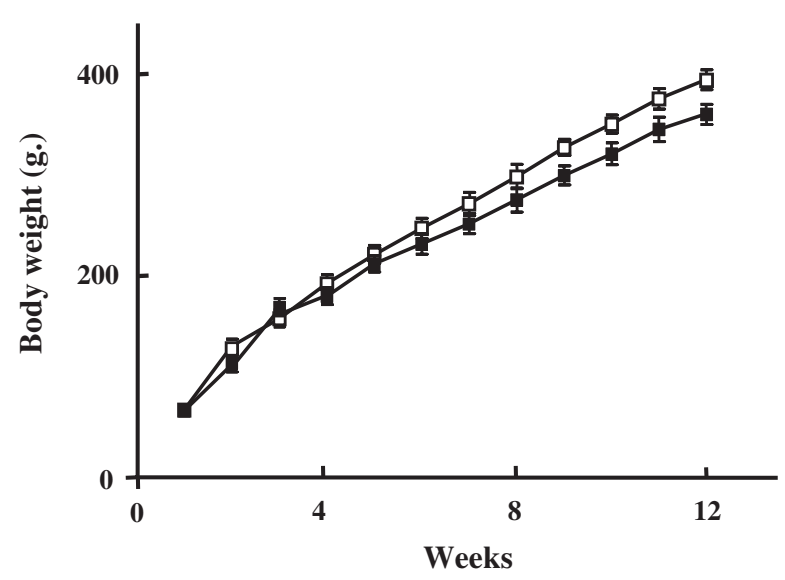

Fig. 1. Effect of $V A D$ on body weight. Each point is the mean \pm S.E.M. of five experiments: Points correspond to control rats $(O)$ or rats fed a VA deficient diet (@). Statistical comparison versus control ${ }^{* *} P<0.01$. 


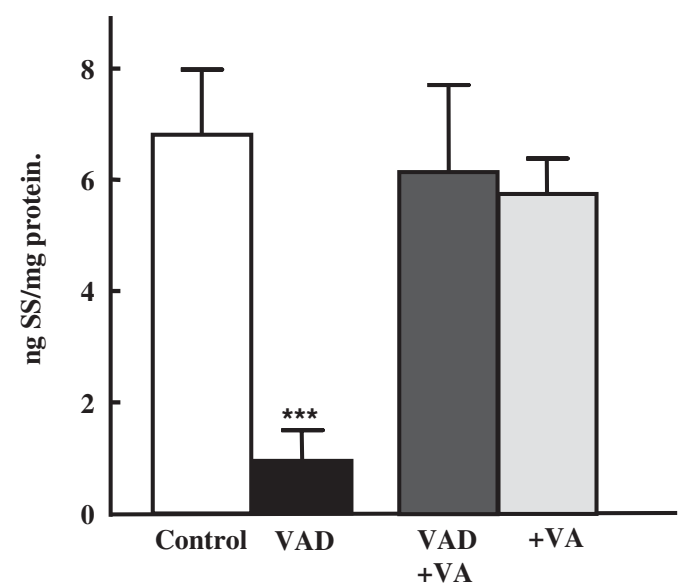

Fig. 2. Effect of a VA-free diet (VAD) on SS-LI content in the rat hippocampus from control and experimental groups: rats fed a $V A D$, rats fed a standard chow and treated with $V A(+V A)$, and rats fed a VA-free diet treated with VA (VAD+VA). Data are expressed as the mean \pm S.E.M. of five separate experiments, each performed in duplicate. Statistical analysis was performed by ANOVA. **** $P<0.001$.

As Sst are coupled to AC in an inhibitory fashion, we next examined basal and FK-stimulated AC activity as well as SS-mediated inhibition of this enzyme in hippocampal membranes. No significant differences in either basal or FK stimulated AC activity were detected among the experimental groups (Table 4). In addition, basal and FK-stimulated AC activity was inhibited by SS in all the groups studied. However, the capacity of SS to inhibit both activities in these membranes was significantly lower in the rats fed a VA-free diet (Table 4). VA administration to these rats returned these values to control levels.

All Sst subtypes are known to couple to $A C$ via $\mathrm{Gi}$ proteins. Hence $\mathrm{Gi}$ activity was evaluated by use of the non-hydrolyzable GTP analog Gpp(NH)p, analyzing its effects on FK $\left(3.10^{-5} \mathrm{M}\right)$-stimulated AC activity. Increasing concentrations of $\mathrm{Gpp}(\mathrm{NH}) \mathrm{p}$ generated a characteristic biphasic curve, with a decrease in $\mathrm{AC}$ activity in the range of $10^{-11}-10^{-7} \mathrm{M} \mathrm{Gpp}(\mathrm{NH}) \mathrm{p}$ and an increase in activity there- after. The inhibitory portion of the curve is a result of the early activation of the $\mathrm{Gi}$ proteins, with higher concentrations activating $\mathrm{Gs}$ proteins. Thus, the first half of the curve serves as a valuable index of $\mathrm{Gi}$ functionality. As shown in Fig. 6, Gi functionality was decreased in hippocampal membranes from rats fed a VA-free diet as compared with controls. This effect reverted to control values after VA administration to these rats.

We next evaluated whether the Gi protein levels were altered under these conditions. The $\alpha$-subunits of $\mathrm{Gi} \alpha_{1}$, $\mathrm{Gi} \alpha_{2}$ and $\mathrm{Gi} \alpha_{3}$ were quantitated by Western blotting using specific anti-Gi $\alpha$ antisera. The results obtained reveal no changes in the protein levels of any of these $G$ protein subunits in hippocampal membranes from the rats fed a VA-free diet. Subsequent VA administration to these rats, however, caused a significant increase in $\mathrm{Gi} \alpha_{1}$ and $\mathrm{Gi} \alpha_{2}$ levels (Fig. 7).

\section{DISCUSSION}

In the present study, animals were fed a VA-free diet for 12 weeks. Following this period, the rats showed clear signs of VAD such as damaged conjunctival epithelium, loss of body fat and a reduction in body weight gain with respect to control rats, as described by Cocco et al. (2002).

Our data show an impairment of the hippocampal SSergic system in rats fed a VA-free diet for 12 weeks. Subsequent administration of VA to these VA-deprived rats partially reversed this impairment.

The SS-LI levels found in the control animals were similar to those previously reported by our group and other authors (Puebla and Arilla-Ferreiro, 2003; Patel and Reichlin, 1978). Rats fed a VA-free diet, however, exhibited a significant reduction of SS-LI levels in the hippocampus, although the SS mRNA levels were unaltered. This apparent discrepancy might be due to decreased proSS biosynthesis and/or posttranslational processing, enhanced SS degradation or increased cellular release, exceeding the rate of SS production. This deficit could be related to a reduction in the rate of proteolytic processing of SS precursors. Two proprotein convertases (PC), PC1 and PC2,

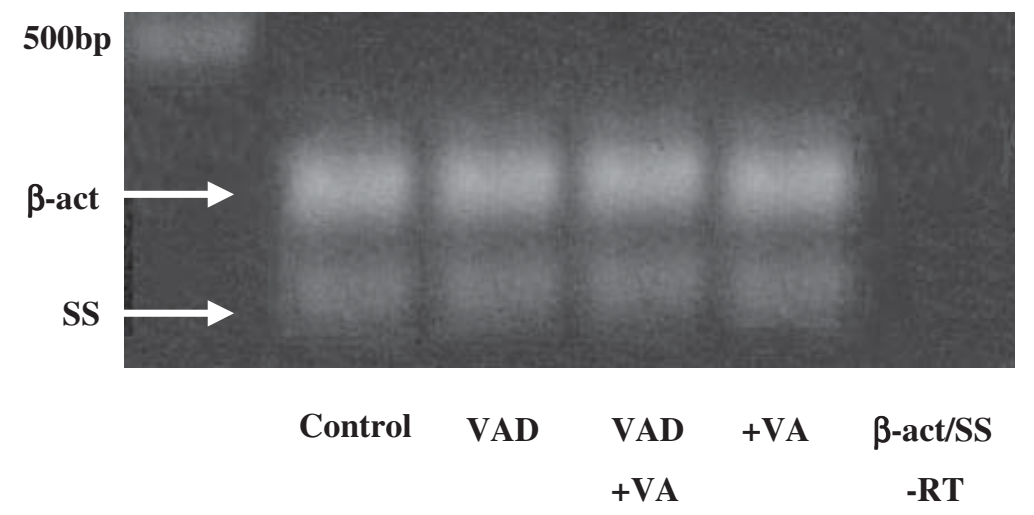

Fig. 3. Detection of rat hippocampal SS mRNA expression by RT-PCR. Total RNA isolated from control and experimental groups [rats fed a VA-free diet (VAD), rats fed a standard chow and treated with VA (+VA), and rats fed a VA-free diet treated with VA (VAD+VA)] was subjected to RT-PCR with specific primers for SS and $\beta$-actin. To control for contaminating cDNA, samples were processed in an identical manner except reverse transcriptase was omitted (labeled "SS/ $\beta$-act-RT"). Products were visualized by agarose gel electrophoresis and ethidium bromide staining. 


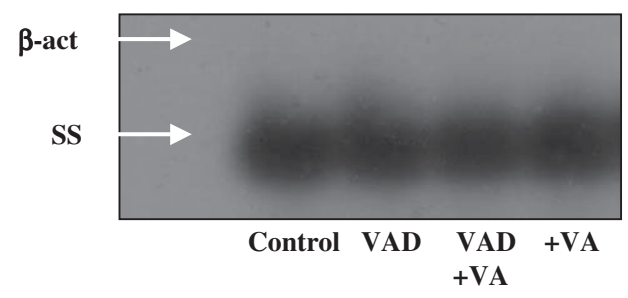

A

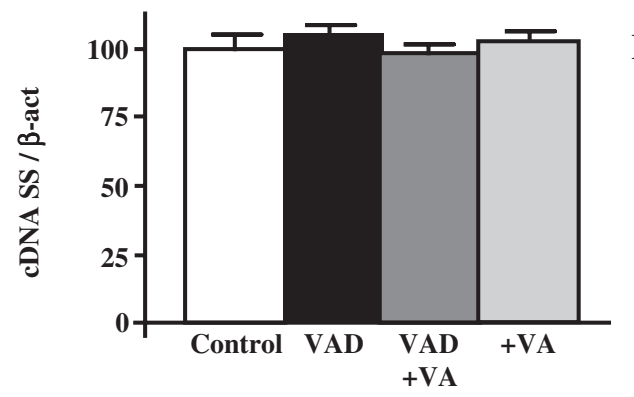

Fig. 4. (A) Southern blot analysis of RT-PCR products. SS RT-PCR products were transferred to a nylon membrane and incubated with a ${ }^{32} \mathrm{P}$-labeled SS-specific probe. To control for nonspecific binding, $\beta$-actin products were also included on the blot. Bound probe was visualized by autoradiography. (B) Summary of the results of control and experimental groups: rats fed a VA-free diet (VAD), rats fed a standard chow and treated with VA (+VA), and rats fed a VA-free diet and then treated with VA $(\mathrm{VAD}+\mathrm{VA})$. The densitometric analysis of the SS expression was corrected with the respective $\beta$-actin expression. Data are expressed as the mean \pm S.E.M. of five separate experiments.

are known to be responsible for the processing of neuropeptide precursors directed to the regulated secretory pathways. In vivo, pross is a physiological substrate of $\mathrm{PC} 2$, an enzyme which is required for the generation of brain SS-14 from the precursor (Winsky-Sommerer et al., 2003). PC2 mRNA is abundant in fields CA1, CA2 and CA3 of the hippocampus, with lower expression in the

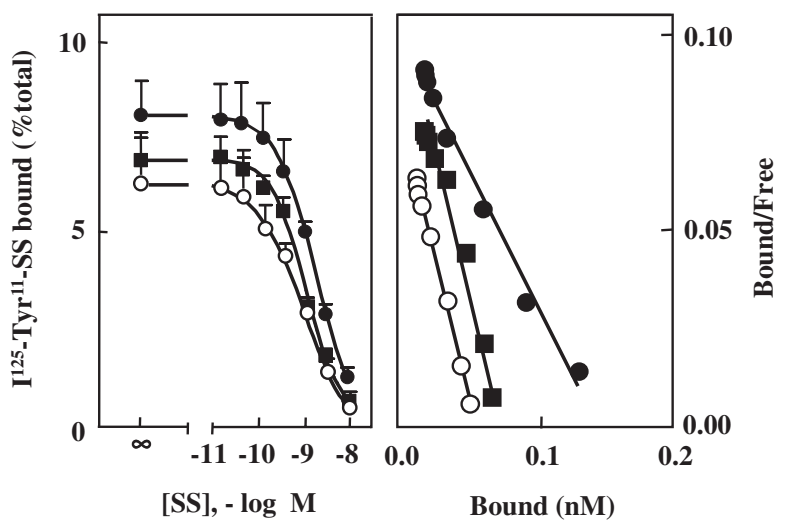

Fig. 5. Left panel: Competitive inhibition of specific ${ }^{125}$ I-Tyr ${ }^{11}$-SS binding by unlabeled SS to rat hippocampal membranes. Specific binding was computed as described in Experimental Procedures. Membranes $(0.15 \mathrm{mg}$ protein $/ \mathrm{ml})$ were incubated for $60 \mathrm{~min}$ at $30^{\circ} \mathrm{C}$ in the presence of $250 \mathrm{pM}{ }^{125}$-Tyr ${ }^{11}$-SS and increasing concentrations of SS. Points correspond to values for the animals in the control group $(O)$, rats fed a VA-free diet $(\bullet)$, and rats fed a VA-free diet treated with VA (匹). Each point is the mean \pm S.E.M. of five separate experiments, each performed in duplicate. Right panel: Scatchard analysis of the binding data.
Table 2. Equilibrium parameters for SS binding in hippocampal membranes from control rats, rats fed a vitamin A-free diet (VAD), rats fed a $V A D$ and then treated with $V A(V A D+V A)$ and rats fed a standard chow and treated with VA (+VA)

\begin{tabular}{lll}
\hline Group & \multicolumn{2}{l}{ SS receptor } \\
\cline { 2 - 3 } & $\mathrm{K}_{\mathrm{d}}$ & $\mathrm{B}_{\max }$ \\
\hline Control & $0.61 \pm 0.12$ & $445 \pm 63$ \\
VAD & $1.24 \pm 0.18^{* *}$ & $979 \pm 59^{* *}$ \\
VAD+VA & $0.56 \pm 0.05$ & $514 \pm 72$ \\
+ VA & $0.66 \pm 0.11$ & $487 \pm 19$ \\
\hline
\end{tabular}

Binding parameters calculated from Scatchard plots by linear regression. Units for dissociation constant $\left(\mathrm{K}_{\mathrm{d}}\right)$ are $\mathrm{nM}$, and units for maximal bound $\left(B_{\text {max }}\right)$ are femtomoles of $S S$ bound per $m g$ of protein. Values represent the mean \pm S.E.M. of five separate experiments each performed in duplicate. Statistical comparison vs. control: ${ }^{* *} P<0.01$.

dentate gyrus (Shen et al., 2005). Furuta et al. (1997) showed that proSS processing is severely impaired in pancreatic islets of PC2 - /- mice. Recently, Shen et al. (2005), using the human PC2 promoter transiently transfected into GH-3 cells, found that 9-cis-RA treatment stimulates PC2 promotor activity whereas the absence of 9-cis-RA inhibits it. These studies suggest that the decreased SS-LI levels in rats fed a VA-free diet might be due to an impairment in the conversion of proSS to SS.

On the other hand, calcium accumulation in the brain of VA-deficient rats has been reported (Rahman et al., 1996). Calcium entry into the cells triggers SS release and causes a depletion of its intracellular stores (de los Frailes et al., 1990). Hence there lies the possibility that the increase of intracellular calcium in rats feds a VA-free diet could be, at least partially, implicated in the decrease of SS-LI levels found in the hippocampus.

Canon et al. (2004) recently reported rapid effects of the VA metabolite RA on cyclic AMP response elementbinding (CREB) phosphorylation in PC12 cells and primary cultures of rat cerebrocortical cells. Since the cAMP response element (CRE) of the SS promotor contains binding sites for CREB that are essential for CAMP-regulated transcription (Montminy and Bilezkijan, 1987; Andrisani and Dixon, 1990; Montminy et al., 1996), one might expect that the reduction of SS-LI induced by VAD could be due to a decreased transcription of the SS gene. However, we detected no changes in the SS mRNA levels among the different experimental groups. This finding is in agreement with a previous report showing that RA does not directly modify SS gene expression (Liu et al., 1994).

Alternatively, the changes in SS-LI content observed here might be, to a certain extent, secondary to the cholinergic dysfunction described by Cocco et al. (2002) in VAD. It should be kept in mind that there is a close neuronal interaction between the somatostatinergic and cholinergic systems in the mammalian hippocampus and cortex, as indicated by a number of electrophysiological (Mancillas et al., 1986; Matsuoka et al., 1991), neurochemical (Araujo et al., 1990; Barrios et al., 1990; Gaykema et al., 1991; Zee et al., 1991; Álvaro and Arilla, 1992) and behavioral studies (Haroutunian et al., 1989; Ohno et al., 
Table 3. Densitometric analysis of the autoradiographs derived from the immunoblots of the hippocampal sst subtype 1-4 from control and experimental groups: rats fed a VA-free diet (VAD), rats fed a VAD and then treated with $V A$ (VAD+VA) and rats fed a standard chow and treated with VA (+VA)

\begin{tabular}{lllll}
\hline Group & Optical density & & & \\
\cline { 2 - 5 } & sst1 & sst2 & sst3 & sst4 \\
\hline Control & 100 & 100 & 100 & 100 \\
VAD & $293.12 \pm 40.16^{* *}$ & $171.11 \pm 24.89^{*}$ & $179.84 \pm 17.71^{* *}$ & $176.76 \pm 14.57^{* *}$ \\
VAD+VA & $116.50 \pm 31.28$ & $174.31 \pm 25.47^{*}$ & $105.53 \pm 10.42$ & $103.33 \pm 11.73$ \\
+VA & $111.10 \pm 5.21$ & $170.72 \pm 21.38^{*}$ & $114.17 \pm 8.35$ & $110.82 \pm 12.45$ \\
\hline
\end{tabular}

Proteins were transferred to nitrocellulose membranes and the immunodetection was carried out by using goat anti-sst(1-4) polyclonal antibodies. For details, see the Experimental Procedures section. Data are expressed as a percent of the control value and represent the mean \pm S.E.M. of five separate experiments. $\beta$-Tubulin blots were used as controls to correct for loading in each lane. Statistical comparison vs. control: * $P<0.05 ;{ }^{* *} P<0.01$.

1993). In the rat hippocampus, cholinergic terminals make synaptic contacts on SS-immunoreactive cells (Leranth and Frotscher, 1987). In addition, Nakata et al. (1996) suggest that SS facilitates the generation of perforant path-dentate gyrus granule cell LTP by activating the muscarinic cholinergic receptor, an effect which is induced, at least partly, by Sst subtypes 2 and 4 in vivo. Indeed, it has been demonstrated that intraventricular infusion of the immunotoxin 192 lgG-saporin, a highly specific toxin for cholinergic neurons, can lead to a significant reduction of SS in the cerebral cortex and the hippocampus, and that the degree of reduction is highly correlated with that of choline acetyltransferase activity (Nag and Tang, 1998). This seems to be in agreement with a study by Zhang et al. (1998) who showed that selective lesions of the cholinergic basal forebrain can also lead to a loss of somatostatinergic neurons. Hence, the decreased SS content may primarily result from the reduction of acetylcholine in the hippocampus previously reported by Araujo et al. (1990).

The equilibrium parameters of the Sst as well as the protein levels of sst1-4 in the hippocampus of control rats were similar to those previously reported by our group and other authors (Aguado-Llera et al., 2005; Hervás-Aguilar et al., 2005; Epelbaum et al., 1982; Srikant and Patel, 1981). In the present study, the depletion of hippocampal SS-LI levels in rats fed a VA-free diet was accompanied by an increase of SS binding concomitant with an increase in the protein levels of sst (1-4). Although the molecular mechanism is unknown, changes in SS-LI levels and in glucocorticoid receptor (GR) activity under the present condi- tions may be involved. It should be noted that other in vivo studies have demonstrated an upregulation of brain Sst in SS-deficient mice (Ramírez et al., 2002). Moreover, chemical depletion of rat brain SS with cysteamine has been shown to up-regulate cortical membrane SS binding sites (Srikant and Patel, 1984). Our group has also previously reported an increase in SS binding in the cytosol of gastric and duodenal mucosa accompanied by a decrease of SS-LI levels in rats treated with cysteamine (GonzálezGuijarro et al., 1986, 1987). Altogether, our results suggest that a decrease in endogenous SS-LI levels leads to the up-regulation of Sst.

Alternatively it has been shown that the binding capacity of the GR is higher in VAD rats than in controls (Audouin-Chevallier et al., 1995). Our group previously demonstrated that the density of receptors (binding sites) for ${ }^{125} \mathrm{I}-\mathrm{Tyr}^{11}$-SS in certain brain areas increases in response to glucocorticoids (Rodríguez et al., 1988). Hence, there lies a possibility that an increase in the GR density described in VAD could lead to an increase in Sst density.

VA administration to rats previously kept on a VA-free diet reversed the observed decrease in SS-LI levels as well as the increase in SS binding and sst1, sst3 and sst4 protein levels to control values. However, sst2 levels remained enhanced after restitution of VA. This finding might partly be explained by the fact that although VA administration to VAD animals normalizes GR density, it increases it affinity constant (Ka), stimulating sst2 gene expression in neuronal tissue (Kraus et al., 1999). To date, only the sst2 gene has been reported to contain consensus glucocorti-

Table 4. Basal and FK-stimulated AC activity (pmol cAMP/min/mg protein) in hippocampal membranes from control and experimental groups: rats fed a standard chow and treated with VA (+VA), rats fed a VA-free diet (VAD) and rats fed a VAD and then treated with VA (VAD+VA)

\begin{tabular}{lcccc}
\hline & Control & + VA & VAD & VAD + VA \\
\hline Basal & $540.2 \pm 100.0$ & $420.9 \pm 35.8$ & $307.2 \pm 81.2$ & $349.9 \pm 82.0$ \\
$+10^{-4}$ M SS & $279.1 \pm 59.9$ & $287.3 \pm 51.7$ & $220.3 \pm 85.7$ & $198.5 \pm 51.7$ \\
$+10^{-5}$ M FK & $1085.1 \pm 350.0$ & $1129.0 \pm 403.1$ & $733.9 \pm 377.2$ & $716.9 \pm 215.7$ \\
$+10^{-5}$ M FK $+10^{-4}$ M SS & $662.8 \pm 247.0$ & $713.9 \pm 230.6$ & $494 \pm 207$ & $462.4 \pm 161.0$ \\
Fold FK stimulation over basal & $2.4 \pm 0.4$ & $2.6 \pm 0.9$ & $2.4 \pm 1$ & $30 \pm 7^{* *}$ \\
$\%$ SS inhibition of basal activity & $48 \pm 2$ & $36 \pm 7^{*}$ & $28 \pm 0.7$ \\
$\%$ SS inhibition of FK-stimulated activity & $38 \pm 15$ & $35 \pm 6$ & $44 \pm 5$ \\
\hline
\end{tabular}

Membrane preparations were incubated with or without somatostatin (SRIF) $\left(10^{-4} \mathrm{M}\right)$ in the absence or presence of FK $\left(10^{-5} \mathrm{M}\right)$. Values represent the mean \pm S.E.M. of five separate experiments, each performed in duplicate. Statistical comparison vs. control: ${ }^{*} P<0.05 ;{ }^{* \star} P<0.01$. 


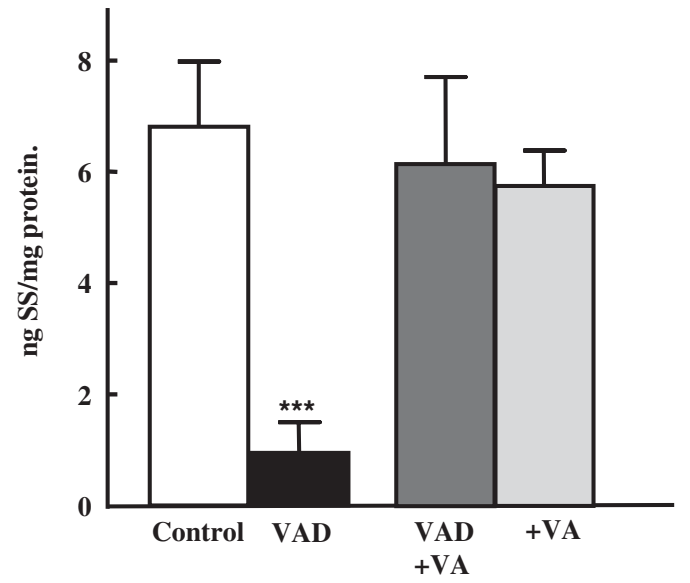

Fig. 6. Dose-effect curves for $\mathrm{Gpp}(\mathrm{NH}) \mathrm{p}$-mediated inhibition of $\mathrm{AC}$ activity in rat hippocampal membranes from control and experimental groups: rats fed a VA-free diet (VAD), rats fed a standard chow and treated with $\vee A(+V A)$, and rats fed a VA-free diet and treated with VA $(\mathrm{VAD}+\mathrm{VA})$. The effect of $\mathrm{Gpp}(\mathrm{NH}) \mathrm{p}$ on AC activity was measured in the presence of $3 \times 10^{-6} \mathrm{M} \mathrm{FK}$ and the indicated concentrations of $\mathrm{Gpp}(\mathrm{NH}) \mathrm{p}$. Data are expressed as a percentage of FK-stimulated AC activity in the absence of $\mathrm{Gpp}(\mathrm{NH}) \mathrm{p}(100 \%)$. The results are given as the mean \pm S.E.M. of five separate determinations, each performed in duplicate. Statistical comparison versus control ${ }^{* *} P<0.01{ }^{* * *} P<0.001$.

coid response elements (GRE) in the promotor sequence and to be transcriptionally regulated by glucocorticoids (Kraus et al., 1998, 1999). Hence, the increase in sst2 protein levels detected in the hippocampus of VA deficient rats when supplemented with VA might also be attributed, partly, to the increase in the GR affinity constant.

A very high concentration of $\mathrm{SS}\left(10^{-4} \mathrm{M}\right)$ was required to produce inhibition of $A C$ activity. This concentration, however, is in agreement with that used by Garlind et al. (1992) and Schettini et al. (1989) in their studies on SSmediated inhibition of AC activity in rat and human brain. In view of the different response of neuronal and glial cells to AC inhibition by SS, the cell heterogeneity of our membrane preparations might explain this high concentration required to obtain inhibition of the enzyme, both by our group and other authors (Izquierdo-Claros et al., 2001; Garlind et al., 1992; Nagao et al., 1989).

SS-mediated inhibition of AC activity was significantly reduced in hippocampal membranes from rats fed a VAfree diet. This is not due to a defect in the catalytic subunit of the enzyme since no changes in basal or FK-stimulated $A C$ activity were detected between control rats and rats fed a VA-free diet. As Sst are negatively coupled to $A C$ via Gi proteins, the decreased capacity of SS to inhibit AC may be a direct consequence of the reduction in Gi functionality and/or $\mathrm{Gi} \alpha$ levels. A decrease in $\mathrm{Gpp}(\mathrm{NH}) \mathrm{p}$-mediated inhibition of FK-stimulated AC activity was, in effect, detected in hippocampal membranes from rats fed a VA-free diet as compared with controls, indicating a loss of functional Gi protein.

The present results further raise the possibility that the spatial learning and memory impairment previously observed by Cocco et al. (2002) in VAD might not be entirely attributed to the reduction of cholinergic activity. Although there is ample evidence for the importance of acetylcholine in hippocampal-dependent mnemonic tasks (Blokland, 1996), the possible role of SRIF in mnemonic functions has also been demonstrated. Cysteamine has been shown to impair hippocampal-sensitive spatial learning when administered systemically (Matsuoka et al., 1995) or infused directly into the hippocampus (Guillou et al., 1998). Experiments using intrahippocampal injections of SS or cysteamine have provided evidence that both facilitatory and impairing effects can be observed, depending on the task used (Lamirault et al., 2001). In addition, the bidirectional effects of cysteamine on learning have been reported to be associated with bidirectional testing-induced changes in hippocampal AC activity (Guillou et al., 1998). There is a growing body of evidence suggesting that spatial learning induces differential (opposite) changes in AC-I and AC-II mRNA expression in the hippocampus of mice (Guillou et al., 1998).

Altogether, the results presented here clearly indicate that dietary VA levels modulate the somatostatinergic sys-
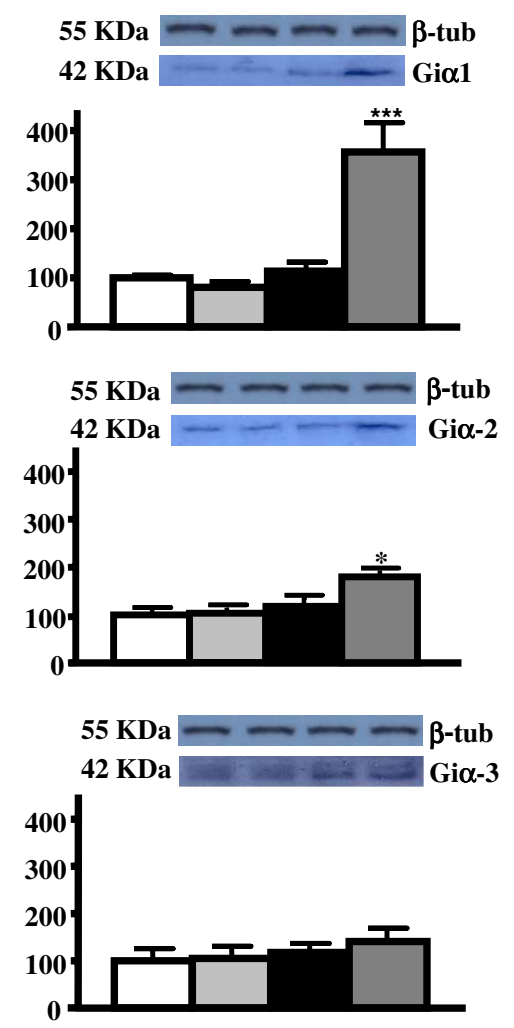

Fig. 7. Densitometric analysis of the autoradiographs derived from the immunoblots of the $\alpha \mathrm{i} 1, \alpha \mathrm{i} 2$ and $\alpha \mathrm{i} 3$ subunits of $\mathrm{G}$ proteins. Hippocampal membranes from control and experimental groups [rats fed a $V A$-free diet (VAD), rats fed a standard chow and treated with VA $(+\mathrm{VA})$, and rats fed a VA-free diet and treated with VA $(\mathrm{VAD}+\mathrm{VA})$ ] were solubilized in SDS-sample buffer. Proteins were analyzed by SDS-PAGE and transferred to nitrocellulose membranes as described in the Experimental Procedures section. The immunodetection was achieved using mouse anti-Gi $\alpha 1$ or anti-Gi $\alpha 2$ monoclonal antibodies or a rabbit anti-Gi $\alpha 3$ polyclonal antibody. The integrated optical densities for autoradiographs are presented as a percentage of the control value. Data represent the mean \pm S.E.M. of five separate determinations. Statistical comparison versus control * $P<0.05{ }^{* *} P<0.01$. 
tem in the rat hippocampus. Although the significance of these changes in the Sst-effector system induced by VAD remains to be established, these findings are of interest given the fact that both VA and SS affect spatial learning and memory.

Acknowledgments-We wish to thank the staff of the Animal Centre of the Universidad de Alcalá for their support with the animal care and handling. This work was supported by a grant (SAF 2003-08052) from the Dirección General de Investigación del Ministerio de Ciencia y Tecnología of Spain.

\section{REFERENCES}

Aguado-Llera D, Arilla-Ferreiro E, Campos-Barros A, Puebla-Jiménez L, Barrios V (2005) Protective effects of insulin-like growth factor I on the somatostatinergic system in the temporal cortex of betaamyloid-treated rats. J Neurochem 92(3):607-615.

Aguilera G, Parker DS, Catt KJ (1982) Characterization of somatostatin receptor in the rat adrenal glomerulose zone. Endocrinology 111:1376-1384.

Álvaro I, Arilla E (1992) Somatostatin receptor elevation in rat striatum after diisopropylfluorophosphate administration. Brain Res Bull 28: 513-518.

Andrisani OM, Dixon JE (1990) Somatostatin gene regulation. Annu Rev Physiol 52:793-806.

Araujo DM, Lapchak PA, Collier B, Quirion R (1990) Evidence that somatostatin enhances endogenous acetylcholine release in the rat hippocampus. J Neurochem 55:1546-1555.

Audouin-Chevallier I, Pallet V, Coustaut M, Alfos S, Higueret P, Garcin $H$ (1995) Retinoids modulate the binding capacity of the glucocorticoid receptor and its translocation from cytosol to nucleus in liver cells. J Steroid Biochem Mol Biol 52:321-328.

Barrios V, Rodríguez-Sánchez MN, Arilla E (1990) The effect of chronic administration of nicotine and withdrawal on somatostatin concentration and binding in brain of rat. Neuropharmacology 29:1025-1030.

Bennett GW, Ballard TM, Watson CD, Fone KC (1997) Effect of neuropeptides on cognitive function. Exp Gerontol 32:451-469.

Bieri JG, Tolliver TJ, Catignani GL (1979) Simultaneous determination of alpha-tocopherol and retinol in plasma or red cells by high pressure liquid chromatography. Am J Clin Nutr 32(10):21432149.

Bissette G, Myers B (1992) Somatostatin in Alzheimer's disease and depression. Life Sci 51:1389-1410.

Bliss TVP, Collingridge GL (1993) A synaptic model of memory: Long term potentiation in the hippocampus. Nature 361:31-39.

Blokland A (1996) Acetylcholine: A neurotransmitter for learning and memory? Brain Res Rev 21:285-300.

Canon E, Cosgaya JM, Scsucova S, Aranda A (2004) Rapid effects of retinoic acid on CREB and ERK phosphorylation in neuronal cells. Mol Biol Cell 15(12):5583-5592.

Chambon P (1996) A decade of molecular biology of retinoic acid receptors. FASEB J 10:940-954.

Chiang MY, Misner D, Kempermann G, Schikarski T, Giguère V, Sucov HM, Gage FH, Stevens CF, Evans RM (1998) An essential role for retinoid receptors $\operatorname{RAR} \beta$ and $\operatorname{RxR} \gamma$ in long-term potentiation and depression. Neuron 21:1353-1361.

Cocco S, Díaz G, Stancampiano R, Diana A, Carta M, Curreli R, Sarais L, Fadda F (2002) Vitamin A deficiency produces a spatial learning and memory impairment in rats. Neuroscience 115:475-482.

Csaba Z, Dournaud P (2001) Cellular biology of somatostatin receptors. Neuropeptides $35: 1-23$.

Czernik AJ, Petrack V (1983) Somatostatin receptor binding in rat cerebral cortex. Characterization using a nonreductible somatostatin analog. J Biol Chem 285:5525-5530. de los Frailes MT, Sánchez-Franco F, Lorenzo MJ, FernándezVázquez G, Cacicedo L (1990) Depolarizing influences regulate somatostatin synthesis and processing in cultured cerebral cortical cells. Regul Pept 27(1):97-105.

Dowling JE, Wald G (1960) The biological function of vitamin A acid. Proc Natl Acad Sci U S A 46:597-608.

Epelbaum J, Tapia-Arancibia L, Kordon C, Enjalbert A (1982) Characterization, regional distribution and subcellular distribution of ${ }^{125}$ - Tyr $^{11}$-somatostatin binding sites in rat brain. $J$ Neurochem 38:1515-1523.

Etchamendy N, Enderlin V, Marighetto A, Pallet V, Higueret P, Jaffard R (2003) Vitamin A deficiency and relational memory deficit in adult mice: relationships with changes in brain retinoid signalling. Behav Brain Res 145(1-2):37-49.

Fitzgerald LW, Dokla CP (1989) Morris water task impairment and hypoactivity following cysteamine-induced reductions of somatostatin-like immunoreactivity. Brain Res 505(2):246-250.

Freund TF, Buzsaki G (1996) Interneurons of the hippocampus. Hippocampus 6(4):347-470.

Furuta M, Yano H, Zhan A, Rouville Y, Holst JJ, Carrod R, Ravazzola M, Orci L, Furuta H, Steiner DF (1997) Defective prohormone processing and altered pancreatic islet morphology in mice lacking active SPC2. Proc Natl Acad Sci U S A 94:6646-6651.

Garlind A, Fowler CJ, Alafuzoff I, Winblad B, Cowburn RF (1992) Neurotransmitter-mediated inhibition of post-mortem human brain adenylyl cyclase. J Neural Transm 87:113-124.

Gaykema RPA, Gaal G, Traber J, Hersh LB, Luiten PGM (1991) The basal forebrain cholinergic system: efferent and afferent connectivity and long term effects of lesions. Acta Psychiatr Scand Suppl 366:14-26.

Gilman AG (1970) A protein binding assay for adenosine $3^{\prime} 5^{\prime}$-cyclicmonophosphate. Proc Natl Acad Sci U S A 67:305-312.

Glowinski J, Iversen LL (1996) Regional studies of catecholamines in the rat brain I. The disposition of $\left[{ }^{3} \mathrm{H}\right]$ norepinephrine, $\left[{ }^{3} \mathrm{H}\right]$ dopamine and $\left.{ }^{3} \mathrm{H}\right] \mathrm{DOPA}$ in various regions of the brain. $\mathrm{J}$ Beurochem 13:655-669.

González-Guijarro L, López-Ruiz MP, Bodegas G, Prieto JC, Arilla E (1987) Effect of cysteamine on cytosolic somatostatin binding sites in rabbit duodenal mucosa. Exp Mol Pathol 46:153-158.

González-Guijarro L, López-Ruiz MP, Prieto JC, Arilla E (1986) Modulation of somatostatin binding sites in cytosol of rabbit gastric fundic mucosa by cysteamine administration. Gen Pharmacol 17: 637-639.

Greenwood FC, Hunter WH, Glover JS (1963) The preparation of ${ }^{131}$ I-labelled human growth hormone of high specific radioactivity. Biochem J 89:114-123.

Guillou JL, Micheau J, Jaffard R (1998) The opposite effects on cysteamine on the acquisition of two different tasks in mice are associated with bidirectional testing-induced changes in hippocampal adenylyl cyclase activity. Behav Neurosci 112:900-908.

Han ZS, Buhl EH, Lorinszi Z, Somogyi P (1993) A high degree of spatial selectivity in the axonal and dendritic domains of physiologically identified local-circuit neurons in the dentate gyrus of the rat hippocampus. Eur J Neurosci 5:395-410.

Haroutunian V, Kanof PD, Davis KL (1989) Interaction of forebrain cholinergic and somatostatinergic systems in the rat. Brain Res 496:98-104.

Hervás-Aguilar A, Puebla-Jiménez L, Burgos-Ramos E, Aguado-Llera $D$, Arilla-Ferreiro E (2005) Effects of single and continuous administration of amyloid beta-peptide (25-35) on adenylyl cyclase activity and the somatostatinergic system in the rat frontal and parietal cortex. Neuroscience 135(1):181-190.

Houslay MD, Metcalfe JC, Warren GB, Hesketh TR, Smith GA (1976) The glucagon receptor of rat liver plasma membrane can couple to adenylate cyclase without activating it. Biochim Biophys Acta 436:489-494

Izquierdo-Claros RM, Boyano-Ádanez MC, Torrecillas G, RodríguezPuyol M, Arilla-Ferreiro E (2001) Acute modulation of somatostatin 
receptor function by melatonin in the rat frontoparietal cortex. J Pineal Res 31(1):46-56.

Karbownik M, Brzezianska E, Lewinski A (2005) Increased expression of mRNA specific for thymidine kinase deoxycytidine kinase of thymidine phosphorylase in human papillary thyroid carcinoma. Cancer Lett 225(2):267-273.

Kastner P, Mark M, Chymselinck N, Krezel W, Dupe V, Grandona JM, Chambon P (1997) Genetic evidence that the retinoic signal is transduced by heterodimeric RxR/RAR functional units during mouse development. Development 124:313-326.

Kraus J, Woltje M, Höllt V (1999) Regulation of mouse somatostatin receptor type 2 gene expression by glucocorticoids. FEBS Lett 459:200-204

Kraus J, Woltje M, Schönwetter N, Höllt V (1998) Alternative promoter usage and tissue-specific expression of the mouse somatostatin receptor 2 gene. FEBS Lett 428:165-170.

Lamirault L, Guillou JL, Micheau J, Jaffard R (2001) Intrahippocampal injections of somatostatin dissociate acquisition from the flexible use of place responses. Eur J Neurosci 14(3):567-570.

Lane MA, Bailey SJ (2005) Role of retinoid signalling in the adult brain. Prog Neurobiol 75:275-293.

Leranth C, Frotscher M (1987) Cholinergic innervation of hippocampal GAD- and somatostatin-immunoreactive commissural neurons. J Comp Neurol 261(1):33-47.

Liu JL, Papachristou DN, Patel YC (1994) Glucocorticoids activate somatostatin gene transcription through cooperative interaction with the cyclic AMP signalling pathway. Biochem J 301(3):863869.

Lowry OH, Rosenbrought NJ, Farr AL, Randall RJ (1951) Protein measurement with the Folin phenol reagent. J Biol Chem 193: 265-575.

Maden M, Gale E, Zile M (1998) The role of vitamin A in the development of the central nervous system. J Nutr 128:471S-475S.

Mancillas JR, Siggins GR, Bloom FE (1986) Somatostatin selectively enhances acetylcholine-induced excitations in rat hippocampus and cortex. Proc Natl Acad Sci U S A 83(19):7518-7521.

Mangelsdorf DJ, Evans RM (1995) The RxR heterodimers and orphan receptors. Cell 83:841-850.

Mangelsdorf DJ, Thummel C, Beato M, Herrlich P, Schiitz G, Umesono K, Blumberg B, Katner P, Mark M, Chambon P, Evans RM (1995) The nuclear receptor superfamily: The second decade. Cell 83: 835-839.

Matsuoka N, Yamazaki M, Yamaguchi I (1995) Changes in brain somatostatin in memory-deficient rats: Comparison with cholinergic markers. Neuroscience 66:617-626.

Matsuoka N, Kaneko S, Satoh MA (1991) Facilitatory role of endogenous somatostatin in long-term potentiation of the mossy fiber CA3-system in guinea pig hippocampus. Neurosci Lett 129: $177-180$

Meyerhof W (1998) The elucidation of somatostatin receptor functions: a current view. Rev Physiol Biochem Pharmacol 133:55-108.

Misner DL, Jacobs S, Shimizu Y, de Urquiza AM, Solomin L, Perlmann T, De Luca LM, Stevens CF, Evans RM (2001) Vitamin A deprivation results in reversible loss of hippocampal long-term synaptic plasticity. Proc Natl Acad Sci U S A 98:11714-11719.

Montminy MR, Brindle P, Arias J, Ferreri K, Armstrong R (1996) Regulation of somatostatin gene transcription by cyclic adenosine monophosphate. Metabolism 48(8 Suppl 1):4-7.

Montminy MR, Bilezkijan LM (1987) Binding of a nuclear protein to the cyclic-AMP response element of the somatostatin gene. Nature 328(6126):175-178.

Mumby SM, Kahn RA, Manning DR, Gilman AG (1986) Antisera of designed specificity for subunits of guanine nucleotide-binding regulatory proteins. Proc Natl Acad Sci U S A 83(3):265-269.

Munson PJ, Rodbard D (1980) LIGAND: a versatile computerized approach for characterization of ligand binding systems. Anal Biochem 107:220-239.
Nag S, Tang F (1998) Cholinergic lesions of the rat brain by ibotenic acid and 192lgG-saporin: Effects on somatostatin, substance $P$ and neuropeptide $Y$ levels in the cerebral cortex and the hippocampus. Neurosci Lett 252:83-86.

Nagao M, Sakamoto C, Matozaki T, Nishizaki H, Kondo Y, Nakano O, Baba S (1989) Coupling of inhibitory GTP binding protein to somatostatin receptors on rat cerebrocortical membranes. Front Endocrinol 65:1357-1366.

Nakata A, Saito H, Nishiyama N (1996) Facilitatory role of somatostatin via muscarinic cholinergic system in the generation of long-term potentiation in the rat dentate gyrus in vivo. Brain Res 723 : 135-140.

Ohno M, Shibata S, Yamamoto T, Watanabe S (1993) Working memory deficits following muscarinic blockade combined with depletion of brain somatostatin in rats. Brain Res 610:348-353.

Oliveros L, Vega V, Anzulovich AC, Ramírez D, Giménez MS (2000) Vitamin A deficiency modifies antioxidant defences and essential elements contents in rat heart. Nutr Res 20(8):1139-1150.

Patel YC, Reichlin S (1978) Somatostatin in hypothalamus, extrahypothalamic brain and peripheral tissues of the rat. Endocrinology 102:523-530.

Puebla L, Arilla-Ferreiro E (2003) Modulation of somatostatin receptors, somatostatin content and $\mathrm{Gi}$ proteins by substance $\mathrm{P}$ in the rat frontoparietal cortex and hippocampus. J Neurochem 84(1): 145-156.

Rahman AS, Kimura M, Yokoi K, Naher TE, Itokawa Y (1996) Neurological disorder and excessive accumulation of calcium in brain of clinically vitamin A-deficient rats. Biol Trace Elem Res 53:57-64.

Ramírez JL, Mouchantaf R, Kumar U, Otero-Corchón V, Rubinstein M, Low MJ, Patel JC (2002) Brain somatostatin receptors are upregulated in somatostatin-deficient mice. Mol Endocrinol 16: 1951-1963.

Reubi JC, Perrin MH, Rivier JE, Vale W (1981) High affinity binding sites for a somatostatin-28 analog in rat brain. Life Sci 28: 2191-2198.

Rodríguez MN, Gómez-Pan A, Arilla E (1988) Decrease in number of somatostatin receptors in rat brain after adrenalectomy: normalization after glucocorticoid replacement. Endocrinology 123(2):1147-1152.

Sambrook J, Fritsch EF, Manniatis T (1989) Molecular cloning. A laboratory manual, pp 9.31-9.62. New York: Cold Spring Harbor Laboratory Press.

Scatchard G (1949) The attractions of proteins for small molecules and ions. Ann NY Acad Sci 51:669-671.

Schettini G (1991) Brain somatostatin: receptor-coupled transducing mechanisms and role in cognitive functions. Pharmacol Res 23(3):203-215.

Schettini G, Florio T, Meucci O, Landorfi E, Grimaldi M, Venta C, Marino A (1989) Somatostatin inhibition of adenylate cyclase activity in different brain areas. Brain Res 492:65-71.

Schwartz PT, Vallejo M (1998) Differential regulation of basal and cyclic adenosine $3^{\prime} 5^{\prime}$-monophosphate induced somatostatin gene transcription in neural cells by DNA control elements that bind homeodomain proteins. Mol Endocrinol 12(9):1280-1293.

Sessions GR, Demetriades E, Leber LL, Koob GF (1989) Cysteamineinduced somatostatin depletion and working memory deficit in rats. $15^{\text {th }}$ Meeting of the Society for Neurosciences 288-15.

Shen X, Li QL, Brent GA, Friedman TC (2005) Regulation of regional expression in rat brain PC2 by thyroid hormone. Characterization of novel negative thyroid hormone response elements in the PC2 promoter. Am J Physiol 288:E236-E245.

Sik A, Penttonen M, Ylinen A, Buzsáki G (1995) Hippocampal CA1 interneurons an in vivo intracellular labeling study. J Neurosci 15:6651-6665.

Srikant CB, Patel YC (1984) Cysteamine-induced depletion of brain somatostatin is associated with up-regulation of cerebrocortical somatostatin receptors. Endocrinology 115:990-995. 
Srikant CB, Patel YC (1981) Somatostatin receptors: identification and characterization in rat brain membranes. Proc Natl Acad Sci U S A 78(6):3930-3934.

Thompson JN, Howell JM, Pitt GAJ (1964) Vitamin A and reproduction in rats. Proc R Soc Biol 159:510-535.

Wagner E, Luo T, Drager UC (2002) Retinoic acid synthesis in the postnatal mouse brain marks distinct developmental stages and functional systems. Cereb Cortex 12:1244-1253.

Winsky-Sommerer R, Grouselle D, Rougeot C, Laurent V, David JP, Delacourte A, Dournaud P, Seidah NG, Lindberg I, Trottier S, Epelbaum J (2003) The protein convertase PC2 is involved in the maturation of prosomatostatin to somatostatin-14 but not in the somatostatin deficit in Alzheimer's disease. Neurosci 122(2):437-447.

Winsky-Sommerer R, Benjannet S, Rovére C, Barbero P, Scidah NG, Epelbaum J, Dournaud P (2000) Regional and cellular localization of the neuroendocrine prohormone convertases PC1 and PC2 in the rat central nervous system. J Comp Neurol 424:439-460.

Zappone CA, Sloviter RS (2001) Commissurally projecting inhibitory interneurons of the rat hippocampal dentate gyrus: a colocalization study of neuronal markers and the retrograde tracer Fluoro-gold. J Comp Neurol 441:324-344.
Zee EA, Benoit R, Strosberg AD, Luiten PGM (1991) Coexistence of muscarinic acetylcholine receptors and somatostatin in nonpyramidal neurons of the rat dorsal hippocampus. Brain Res Bull 26:343-351.

Zetterström RH, Lindquist $E$, de Urquiza AM, Tomac A, Eriksson U, Perlman T, Olson T (1999) Role of retinoids in the CNS: differential expression of retinoid binding proteins and receptors and evidence for presence of retinoic acid. Eur J Neurosci 11:407-416.

Zetterström RH, Simon A, Giacobini MM, Eriksson U, Olson L (1994) Localization of cellular retinoid-binding proteins suggests specific roles for retinoids in the adult central nervous system. Neuroscience 62:899-918.

Zhang ZJ, Lappi DA, Wrenn CC, Milner TA, Wiley RG (1998) Selective lesion of the cholinergic basal forebrain causes a loss of cortical neuropeptide $Y$ and somatostatin neurons. Brain Res 800(2): 198-206.

Zhuang Y, Sainio EL, Sainio P, Vedeckins WV, Ylikomi T, Tuohimaa P (1995) Distribution of all-trans-retinoic acid in normal and vitamin A deficient mice. Correlations to retinoic acid receptors and different tissues of normal mice. Gen Comp Endocrinol 100(2):170-178. 